\title{
Implications of HR Outsourcing for HR Practitioners Work Behaviors: Evidence from the Mobile Telecommunication Industry in Ghana
}

\author{
Samuel Howard Quartey ${ }^{1}$ \\ ${ }^{1}$ Central Business School, Central University College, Ghana \\ Correspondence: Samuel Howard Quartey, Department of Human Resource Management, Central Business \\ School, Central University College, P. O. Box 2305, Accra, Ghana. E-mail: squartey@central.edu.gh/ \\ shquartey@gmail.com.
}

Received: August 6, 2013

Accepted: September 9, 2013

Online Published: October 28, 2013

doi:10.5539/ibr.v6n11p178

URL: http://dx.doi.org/10.5539/ibr.v6n11p178

\begin{abstract}
This study examined the implications of Human Resource outsourcing for Human Resource Practitioners work behaviors in the mobile telecommunication industry in Ghana. The assumptions of the resource-based theory served as a lens for providing an understanding into the implications of Human Resource outsourcing for Human Resource Practitioners work behaviors. This study was a descriptive study design which sought to investigate the implications of Human Resource outsourcing for Human Resource Practitioners' work behaviors. The mobile telecommunication industry in Ghana was purposively chosen for its socioeconomic relevance to the Ghanaian economy. Twelve Human Resource Practitioners' consisting of Human Resource Officers and Human Resource Managers from the six mobile telecommunication industry were selected to participate in this study. The results from the descriptive analysis indicated that Human Resource Management functions such as recruitment, employee training, employee health and safety management and human resource information system and activities (such as payroll administration and social security) were more likely to be outsourced. The results further showed that Human Resource outsourcing activities had insignificant effect on Human Resource Practitioners' work behaviors such as job satisfaction, organisational commitment and turnover intentions. Therefore Human Resource outsourcing practices do not have significant implications for Human Resource Practitioners work behaviors. Although Human Resource outsourcing has insignificant effects on Human Resource Practitioners work behaviors, it is highly recommended that managements in the mobile telecommunication industry must reduce their overdependence on financial rewards and rather implement job enrichment and enlargement strategies in making their employees committed, satisfied and stay.
\end{abstract}

Keywords: human resource outsourcing, human resource practitioners, work behaviors, resource-based theory, mobile telecommunication industry, Ghana

\section{Introduction}

Studies on Human Resource outsourcing in developed and developing countries abound. However, there are few studies on the implications of Human Resource outsourcing for Human Resource Practitioners work behaviors. This study is an attempt to investigate the implications of Human Resource outsourcing for Human Resource Practitioners work behaviors in the telecommunication industry in a developing country like Ghana. Human Resource outsourcing as an organisational strategy has increased substantially over the last decades. In recent times, organisations' strategic intent is to operationally adjust in order to achieve competitive advantage. As a result, many organisations have resorted to the formulation and implementation of organisation-wide strategies that guarantee competitive advantage. Organisation-wide strategies commonly implemented by these organisations include, re-engineering, downsizing, internationalisation, technological advancement and just-in-time manufacturing practices (Freeman \& Cameroon, 1993). One of the most frequent and common if not pervasive organisational strategies sharply implemented by organisations is the Human Resource outsourcing (Cooke, Shen \& McBride, 2005). Understanding Human Resource outsourcing as a concept is imperative for its practice. The concept can be understood as a practice of contracting out specific Human Resource functions or activities to a third party with a controlled and flexible relationship (Chaffey, 2003). Since in every contractual relationship there is an exchange of valued resources and rewards, Human Resource outsourcing as a contractual relationship seems to promise a lot of rewards for outsourcing organisations. 
Many have argued that organisations outsource their Human Resource Management functions for many reasons. Some scholars suggested that organisations outsource their Human Resource Management functions due to the need to cut cost, focus on core businesses, ensure greater business flexibility, increase speed and use specialized expertise (Cooke, 2005; Ward, 2004). Other researchers have also argued that the practice is vital for a number of strategic and operational reasons such as to increase capacity, improve quality, increase profitability, increase productivity and improve overall financial performance and growth (Bartlett, 2004; Farrell, 2004; Jasper, 2003). These underlining reasons constitute the motivation for Human Resource outsourcing practices in many organisations today. Apart from the reasons for outsourcing Human Resource Management activities, many researchers have argued that organisations are willing to outsource almost every activity that is transactional in nature. Armstrong (2003) indicated that the Human Resource Management functions that are mostly outsourced include; recruitment and selection, performance appraisal and management, reward or compensation management, health and safety, training and management development, change management and other administrative activities. More empirical evidences also exist to suggest that outsourcing HR functions are prevalent. A cross-national study by AMA (1997) suggested that many organisations have outsourced some of their Human Resources Management functions with an increasing trend in Europe, Asia and Africa.

The trend and growth of Human Resource (HR) outsourcing have indeed been greatly explored. Morgan (2001) argued that, in recent times, many multinational companies including the mobile telecommunication companies are well noted for Human Resource outsourcing practices. Due to the proliferation of Human Resource outsourcing practices, Wright (2008) predicted that the HR outsourcing market would be worth over $\$ 160$ billion by 2012. Since Wright's prediction, there has been an exponential growth in the use of external providers for Human Resource Management functions in almost every industry and country (Hirschman, 2000).

Human Resource outsourcing practices have now become very ubiquitous in the developing and developed economies (Sethi \& Sethi, 2011). Consequently, the fastest growing business process outsourcing services in many countries today is the HR outsourcing (Dell, 2004). Nevertheless, Drucker (2002) argued that outsourcing the entire Human Resource administrative functions which ten years ago barely existed is now growing at a rate of $30 \%$ a year. The above observations suggest that Human Resource outsourcing in multinational companies is increasing exponentially and even so more rapidly in the telecommunication industry. These observations also support the predictions of Wright (2009) that activity of letting out Human Resource functions perhaps may never cease. Human Resource outsourcing (HRO) activities will continue to be part of business strategy for companies of all sizes, ownership and locations.

Besides the motivations, reasons, trend and growth of HR outsourcing practices as an organisation-wide strategy, few researchers and practitioners have actually questioned its implications for employees, particularly for those whose jobs are mostly at risk. That is, we know a lot about the motivations, reasons, trend and growth of Human Resource outsourcing practices but little do we know about the effect that Human Resource outsourcing practices have on employees in the Human Resource Departments in various telecommunication companies. The repercussions of Human Resource outsourcing are not only limited to unemployment issues (Engardio, 2006; Dobbs, 2004) but may also lead to several attitudinal and behavioral aberrations such as low employee commitment, job dissatisfaction and high employee turnover for employees (Marquez, 2007b; KPMG, 2006; Benson, 2002) which consequently affect the development and maintenance of psychological contract in those organisations (Kennedy, Holt, Ward \& Rehg, 2002).

Recent studies have actually focused more on the business case for Human Resource outsourcing than on the human aspects of Human Resource outsourcing. These suggest that Human Resource outsourcing practices have several consequences for Human Resource Professionals (Leverett, Megley \& Kamery, 2004). The above justifications are consistent with the suggestion of Purcell (1996) that we lack the research to make definite statements on the effect of Human Resource outsourcing on employees, particularly those whose jobs are outsourced. He further indicated that what has been conspicuously missing in much of the research is the insider's perspective. The voices of employees on how Human Resource outsourcing practices impact their work behaviours in their organisations. This study aims to fill this research gap by investigating the implications of Human Resource outsourcing for Human Resource Practitioners work behaviors in the mobile telecommunication industry in Ghana. In particular, this study seeks to address the following questions:

- Which Human Resource Management functions are more likely to be outsourced by the mobile telecommunication industry?

- What are the implications of Human Resource outsourcing for Human Resource Practitioners work behaviors in the mobile telecommunication industry? 


\subsection{Theoretical Perspectives on Human Resource Outsourcing}

Human Resource outsourcing suggests the practice of obtaining Human Resource Management services from an external vendors or consultancy firms (Brown \& Wilson, 2005). Outsourcing Human Resource Management functions must be done within the context of controlled and flexible relationship. Empirical evidence exists to show that a controlled and flexible contractual relationship guarantees cost-effectiveness, quality and speed, otherwise, outsourcing organisations may not benefit from this contractual agreement of "buying" Human Resource Management services from an external party (Linder, 2004; Reed, 2001). It is expected that in any business transaction the "seller" must provide quality and speedy services at a reduced price (cost). Without reduced price, it would be a strategic business decision for outsourcing organisations to rather look inside for Human Resource Management services. In this case, Human Resource Practitioners in organisations are required to take the task of providing quality and speedy Human Resource Management services at a reduced cost. This is consistent with the position of Greer et al. (1999) that Human Resource outsourcing connote letting out Human Resource Management activities that would otherwise be performed in-house. Thus, most of these Human Resource Management services can be provided internally through capacity building (Greer et al., 1999).

Cooke et al. (2005) argued that organisations, practitioners and academics could apply both the resource-based and institutional-based theories when making Human Resource outsourcing decisions. This study focuses on the resource-based theory (RBT) to understanding how Human Resource outsourcing activity can best gain competitive advantage. The resource-based theory (RBT) is often used to shed light on the benefits and implications of HR outsourcing as well as the typologies of HR functions mostly and frequently outsourced (Klass, McClendon \& Gainey, 2001). This theory was first propounded by Penrose (1959); then rediscovered by Wernerfelt (1984) and finally developed into a more robust theory by Barney (1991). The basic assumption of this theory is that organisations can gain competitive advantage by concentrating on their core internal resources (abilities, skills, knowledge, capabilities and competencies). These core internal strengths can be properly developed through internal investment than simply saying "where can we buy them". Barney (1991) has argued that organisations can achieve sustained competitive advantage by implementing those strategies that utilize their internal strengths which demand an appropriate level of response to their environmental opportunities while neutralizing their external threats and avoiding internal weaknesses. Arguably, it is strategically insufficient for organisations to outsource their Human Resource functions with the aim of building internal strengths. It is further recognized that responding to the environmental opportunities and threats through Human Resource devolution is cheaper in the short term but costly in the long term. Since the basic tenants of this theory are building capabilities and creating value, it would be extremely difficult for organisations to build internal capabilities and create value by losing its internal strengths, experts and their expertise through Human Resource outsourcing (Kakabadse \& Kakabadse, 2002).

This theory argues that investing in strategic training and development can help build internal capabilities and capacities and create internal value rather than buying competencies and capabilities externally. Therefore, the ideology of out letting Human Resource services to external parties obviously may have implications for the corporate citizenship behaviors of employees such as organisational commitment, employee turnover, employee job involvement and job satisfaction. The above theoretical perspectives provide a lens for analyzing the implications of Human Resource outsourcing for Human Resource Practitioners work behaviors in the mobile telecommunication industry.

\subsection{Current Development in Human Resource Outsourcing in Ghana}

Business Process Outsourcing (BPO) has become a crucial part of service industries worldwide. This rapidly growing organisational strategy has not yet escaped most African countries. Business Process Outsourcing can be conceptualized as the transferability of business processes from an organisation to an external service provider (Duening \& Click, 2005). One major Business Process Outsourcing activity that is greatly deployed by organisations is the Human Resource outsourcing. Subsequently, one African country where HR outsourcing is growing rapidly in size and numbers is Ghana (McCormick, 2011; Barnum, 2001). Consequently, Ghana is now considered as the number one destination for Human Resource outsourcing in Sub-Saharan Africa (Kearney, 2009) as well as and the thirteenth in the top outsourcing countries in the world today (Sourcingline, 2011). There are several factors responsible for the booming Human Resource outsourcing practices in Ghana. It is against this background that Hallard (2011) argues that Ghana has recently become an attractive destination for European and American Human Resource outsourcing firms because of its strategic position on the equator by sharing the same time zone with other developed countries. It is believed that this has contributed greatly to the huge foreign direct investments (FDIs) in Ghana. 
Currently, Human Resource outsourcing is an evolving service industry in Ghana. However, with more and more mobile telecommunication companies looking to rationalize employees on their payroll sheets, the concept has now become a new buzzword. The country's socio-economic profile and stable democratic nature has drawn huge foreign direct investments including Human Resource outsourcing services (Babou, 2010; Kaufmann et al., 2008). The country is also considered as one of the friendliest countries in the world for foreign investors (Forbes Magazine, 2011). The low corporate tax rate of $15 \%$ compared to China $(25 \%)$ and India (34\%) has attracted a lot of foreign firms into the country (KPMG, 2009). The multilingual nature of the country has also increased the influx and growth of multinational and Human Resource outsourcing firms (Parveez, 2009).

Many have also argued that Ghana's huge investments in Information and Communication Technologies (ICTs) and internet infrastructures (Osiakwan \& Foster, 2004); increasing access to broadband internet bandwidth (Malcom, 2006); stable electricity power grid and favorable regulatory environment (Ghana Energy Commission, 2005; Obour, 2010) have contributed to the growth of Human Resource outsourcing firms and activities in the country. Obviously, the above factors have attracted a lot of Human Resource outsourcing firms and mobile telecommunication firms into the country. Further, in terms of control and ownership, majority of the mobile telecommunication companies in Ghana are multinational companies from North America, United Kingdom and East Asian countries.

\subsection{Outsourced Human Resource Management Functions}

Current arguments in Human Resource (HR) outsourcing literature have focused on which Human Resource functions are frequently and commonly outsourced instead of which Human Resource functions must be outsourced by organisations (Finn, 1999). Fortunately, the resource-based theory provides insight on which Human Resource functions must be outsourced. This theory suggests that outsourcing Human Resource functions must be underpinned by strategic reasons. According to this theory, whether the Human Resource functions outsourced are core or non-core, transformational or transactional, there is the need to create value for outsourcing organisations, employees, customers and investors (Ulrich, 1998). Recently, a lot of Human Resource functions are outsourced in many organisations. Several empirical evidence exist to suggests that benefits administration, recruitment, payroll, talent and human capital outsourcing, training and staff development and workforce consulting constitute the major HR functions that are mostly outsourced (Brown \& Wilson, 2005).

Mahoney and Brewster (2002) and Eleanna and Papalexandris (2005) argued that many organisations outsource Human Resource activities such as recruitment and selection, training and development, pay and benefits, mergers and outplacement, performance appraisal systems, Human Resource planning, organisational climate and culture management activities. Armstrong (2003) argued that the wide range of different Human Resource functions that come under the heading of Human Resource outsourcing are training, recruitment, health and safety monitoring and advisory, employee welfare and counseling activities, payroll management and administration, specialist legal advisory services and performance management. Hall and Torrington (1998) also argued that training, management development, recruitment, selection, outplacement, health and safety, quality initiatives, job evaluation and reward strategies are more likely to be outsourced.

In addition, Datar (2003) and Maidment (2003) confirmed that the two most common and often outsourced HR activities are the recruitment and selection activities. A study by Hewitt Associates (2007) and Klaas et al. (2001) found that the most often outsourced HR functions are payroll administration, recruitment and selection, training and development, and performance management including the administrative functions of the Human Resource Departments. There are no universally accepted HR functions that must be outsourced. Empirical evidence exists to suggest that the five main Human Resource Management activities that are frequently outsourced include: attracting, developing, appraising, rewarding and retaining activities.

\subsection{Implications of HR Outsourcing for HR Practitioners Work Behaviors}

Despite the rising popularity of Human Resource outsourcing, the practice has several implications for employees. Literatures have found several implications of Human Resource outsourcing for employees' turnover. While some level of employee turnover is considered appropriate, high levels of employee turnover is simply unacceptable. Beechler and Woodward (2009) observed that the rate of employee turnover is rising due to job cuts as a result of increasing outsourcing activities. Tarique and Schuler (2010) also found that there is a dramatic increase of employee turnover between 30\% and 50\% among Professionals including Human Resource Professionals. Others have found that employees in the Human Resource Departments readily "jump the fence" for the reason of outsourced job duties. Kiplinger (2009) and Kennedy et al. (2002) found that Human Resource outsourcing creates higher levels of job dissatisfaction which subsequently lead to employees leaving their jobs. 
In the same vein, Deery and Kinnie (2004) found that HR outsourcing creates minimal job security as many Human Resource Executives lose their jobs at the end of their employment contracts. Permanent employment contracts for Human Resource Officers have now become "a dream" to be achieved since casual employment contracts have now become acceptable employment standards (Crolius, 2006; Charna, 2004). Many outsourcing organisations also embark on structural changes which result in losing permanent employment opportunities with devastating consequences for their employees. Charara (2004) further argued that the overall economic benefits of Human Resource outsourcing disadvantage employees especially those whose jobs are outsourced. Human Resource outsourcing connotes a unilateral violation of psychological contract which eventually leads to employees feeling betrayed and subsequently leaving their employers (Baruch \& Hind, 1999). In this study, turnover intentions are considered as the most consistent predictor of actual turnover (Barak, Levin, Nissly \& Lane, 2006).

Human Resource outsourcing has serious implications for employees' job satisfaction. Declining levels of job satisfaction have been reported as another demerit of outsourcing Human Resource functions (Dessler, 2008; Ivancevich, 2007; Reilly \& Williams, 2006). The idea and practice of Human Resource outsourcing is positively correlated with job dissatisfaction among employees (Kabst \& Giardini, 2008). Several studies have also found that Human Resource outsourcing strategy is often characterized by low morale, job insecurity and low motivation which successively lead to job dissatisfaction (Kennedy et al., 2002; Cooper, 1999; Worrall \& Cooper, 1997). Gregory (2005) explains that outsourcing creates culture of fear, anxiety, mistrust and disloyalty which eventually leads to job dissatisfaction. Studies by Cheng and Chan (2008) and Nelson et al. (1990) have found that there are lower levels of job satisfaction among Human Resource Managers and Human Resource Officers due to Human Resource outsourcing.

Empirical evidences exist to suggest that outsourcing Human Resource functions has been noted for its adverse effects on organisational commitment. These evidences also argued that organisational commitment whether affective, normative and calculative can be influenced by the increasing rate of "buying HR services" from an external agent. According to the literature, employees' commitments to their organisations have been partial and inconsistent as a result of losing their job roles (Tsui, Pearce, Porter \& Tripoli, 1997) as a result of Human Resource outsourcing. According to Tsui et al. (1997) outsourcing reduces training and development activities which eventually reduce employee organisational commitment. Others have also argued that since outsourcing leads to mistrust between employees and their employers, such climate of untrustworthiness and insecurity create lower levels of organisational commitment (Lepak \& Snell, 1999; Bigley \& Pearce, 1998). Obviously, Human Resource outsourcing adversely affect the Human Resource Practitioners' commitments to their employer organisations (Lieven \& De-Corte, 2008).

\section{Methodology}

\subsection{Sample and Data Collection}

The mobile telecommunication industry was the subject of the data collection. This industry is one of the most important industrial sectors of the Ghanaian economy. The industry was chosen for several reasons. The socioeconomic importance of the mobile telecommunication industry cannot be underestimated. The industry constitutes one of the fastest growing industries in the Ghanaian economy. The industry has contributed so much to the socioeconomic development of Ghana by way of employment, taxes and levies as well as foreign direct investments (GSS Annual Reports, 2010). State Industry Survey conducted by Ghana Statistical Service (GSS) reported that the annual taxes and levies of the industry was $10 \%$ (i.e., \$299 million dollars) of government revenue (GSS Annual Reports, 2010). The same survey showed that the industry employs 1.5 million workers and contributes $2 \%$ to GDP and accounts for 7\% of national investments. Another State Industry Survey by the National Communications Authority (2012) indicates that the level of penetration for the industry was about seventy-four percent (74\%). The mobile telecommunication industry serves approximately over 23 million customers across the whole country.

Recently, this industry is characterised by intense competition which requires huge internal capabilities through sound Human Resource Management practices. However, HR outsourcing as an organisation-wide strategy in this industry is largely under-researched in terms of its implications for Human Resource Professionals work behaviors. This study was a descriptive study which aimed at investigating the implications of Human Resource outsourcing for Human Resource Practitioners work behaviors in the mobile telecommunication industry. The study purposively selected the six major companies from the mobile telecommunication industry namely: Company A, Company B, Company C, Company D, Company E and Company F. These companies were invited to participate in the study and they agreed. The sample element consisted of employees in the Human 
Resource Departments in the mobile telecommunication industry in Ghana. Thus, randomly sampling technique was used to sample two (2) Human Resource Practitioners from each Human Resource Department in the mobile telecommunication industry. Categorically, they were Human Resource Officers and Human Resource Managers. This sampling technique was chosen because it offered each participant an equal chance of being selected for the study. The study used questionnaire as the data collection instrument. Therefore, questionnaires were distributed by personal visits to all the mobile telecommunication companies and their Human Resource Departments. Since the study concerns only employees in the Human Resource Departments, Human Resource Officers and Human Resource Managers were given the questionnaire to complete. Twelve questionnaires were returned within one month.

The data was analysed using descriptive statistics. The descriptive analysis provided the sample characteristics consisting of respondents' gender, age, education, tenure and professional category. The results showed that, $50 \%$ of the respondents were male while $50 \%$ were female. The average age of the respondents was 37.24 years and they have been working for their companies for an average of 3 years. Of the respondents, $33.3 \%$ were first degree holders while $58.3 \%$ had postgraduate degrees. Regarding their professional category, $50 \%$ of respondents were HR Officers while 50\% were HR Managers.

\subsection{Measures}

Organisational commitment was measured using the organisational commitment scale developed by Porter, Steers, Mowday and Boulian (1974). Although this scale was criticized by O'Reilly and Chatman (1986) due to the overlap of some of the items, the selected items were properly edited and few items were removed to help meet the research objectives. The scale drew upon Angle and Perry's (1981) classification of commitment into two (2) namely the affective and calculative commitments. The affective commitment refers to employees' emotional attachment to their organisations whiles the calculative commitment refers to employees' economic analysis of their contributions as against the inducement given by their organisations (Gainey, 2003). Respondents' organisational commitment was measured using an 11 item scale $(\alpha 0.75)$. Using a five point scale (1-Strongly Disagree, 5-Strongly Agree) respondents rated their commitment to their organisations.

Turnover intentions were measured using Lyon's propensity to leave scale designed by Lyons (1981). This scale was thoroughly edited and few items removed. Respondents' intention to quit was measured using a 10 item scale $(\alpha 0.69)$. Using a five point scale (1-Strongly Disagree, 5-Strongly Agree) respondents rated their likelihood of staying at their current jobs or quitting their current jobs. Job satisfaction was also measured using the Macdonald and Macintyre's (1997) generic job satisfaction scale. Respondents' job satisfaction was measured using an 11 item scale $(\alpha 0.82)$. Using a five point scale (1-Strongly Disagree, 5-Strongly Agree) respondents rated their satisfaction with their current jobs. These scales were used because their reliability coefficients were high, with a reliability of 0.75 for organisational commitment, 0.69 for intention to quit and 0.82 for job satisfaction.

Further, respondents were asked to indicate whether their companies have outsourced any of the following HR functions: recruitment, selection, employee training, management development, employee health and safety and human resource information systems (including payroll administration and social security). According to the literature, these constitute some of the Human Resource Management activities that are more likely to be outsourced (Armstrong, 2003; Brown \& Wilson, 2005).

\subsection{Data Analysis}

The response rate was $100 \%$ and a special attention was paid to the validity and reliability of the measures. The validity was controlled by examining the content and construct validity of the items and all results were satisfactory. With the help of the Statistical Package for Social Sciences (Version 17), descriptive statistics was used in analysing the data. Frequencies and percentages were helpful in presenting respondents personal characteristics such as gender, age, education, tenure and professional category. Mean values and standard deviations were also used for interpreting respondents' job satisfaction, turnover intentions and organisational commitment as a result of HR outsourcing. In the following sections, the results obtained in this study are provided in tables. Reliability in this study was tested using Cronbach's alpha. This method was chosen because it is the most commonly accepted method of assessing the internal consistency of a multi-item measurement scale and can help overcome problems that may arise from using other methods such as split halves and test-retest methods (Dillon, Madden \& Firtle, 1990). 


\section{Results}

\subsection{Human Resource Management Functions Outsourced}

The results for Human Resource Management functions that are more likely to be outsourced by the mobile telecommunication industry are presented below in Table 1 .

Table 1. Outsourced human resource management functions

\begin{tabular}{lll}
\hline HR functions & Frequency & Percentage (\%) \\
\hline Recruitment & 5 & 29.4 \\
Selection & 2 & 11.9 \\
Employee training & 3 & 17.6 \\
Management development & 1 & 5.9 \\
Employee health and safety & 3 & 17.6 \\
HR information system & 3 & 17.6 \\
Total & 17 & 100 \\
\hline
\end{tabular}

Source: Field data (2012).

As shown in Table 1, the results show that $29.4 \%$ of the respondents indicated that recruitment activities are more likely to be outsourced. The respondents further agreed that employee health and safety management (17.6\%), employee training $(17.6 \%)$ and human resource information system $(17.6 \%)$ are also more likely to be outsourced by the mobile telecommunication industry.

\subsection{Implications of Human Resource Outsourcing for Human Resource Practitioners Work Behaviors}

The results regarding the implications of Human Resource outsourcing for Human Resource Practitioners work behaviors are presented in Table 2, 3 and 4 below. These results provide the implications of Human Resource outsourcing for Human Resource Practitioners work behaviors such as organisational commitment, job satisfaction and turnover intentions.

Table 2. Mean and standard deviation regarding organisational commitment

\begin{tabular}{llll}
\hline Responses & $\mathrm{N}$ & Mean & SD \\
\hline Proud to be part of the company & 12 & 3.58 & 1.38 \\
Uphold and defend the vision and objectives & 12 & 4.17 & .39 \\
Do anything to stay in the company & 12 & 3.17 & 1.19 \\
Feel loyal to the company & 12 & 1.83 & 1.11 \\
Good company to work for & 12 & 3.75 & .75 \\
Good place to work & 12 & 3.83 & .72 \\
Proud to belong to my department & 12 & 4.25 & .45 \\
Morale in the company is high & 12 & 3.00 & 1.28 \\
Not much to gain by staying here & 11 & 1.91 & 1.04 \\
Never considered moving to another company & 12 & 2.67 & 1.15 \\
Glad to work in this company & 12 & 3.83 & .83 \\
\hline
\end{tabular}

Source: Field data (2012).

As can be seen in Table 2, the results show that Human Resource outsourcing has an implication for Human Resource Practitioners' organisational commitment. According to the results, there is a significant difference between the mean scores and standard deviations for almost all the items relating to Human Resource Practitioners' 
organisational commitment. The results further revealed that there is a significant difference between the mean score and standard deviation for employees being proud to belong to their companies $(M=3.17, S D=1.19)$. Significance difference also exist between the mean score and standard deviation for employees who were proud to belong to their various departments $(\mathrm{M}=3.58, \mathrm{SD}=1.38)$. These results imply that Human Resource outsourcing does not have significant impact on Human Resource Practitioners' organisational commitment.

Table 3. Mean and standard deviation regarding job satisfaction

\begin{tabular}{llll}
\hline Responses & $\mathrm{N}$ & Mean & SD \\
\hline I enjoy my work all the time & 12 & 3.67 & 1.07 \\
My job is interesting and challenging & 12 & 3.8333 & .94 \\
Satisfied with my job & 12 & 3.58 & 1.24 \\
I am noticed when I do good job & 12 & 3.42 & 1.08 \\
Understand my job expectations & 12 & 4.00 & .74 \\
Feel my colleagues treat me with respect & 12 & 4.08 & .67 \\
Feel my views count in my department & 12 & 4.0 & .69 \\
Job uses my skills and knowledge & 12 & 3.92 & .90 \\
Doing a worthwhile job & 12 & 3.75 & .87 \\
I feeling accomplished & 12 & 3.83 & 1.03 \\
Supervisor gives me help & 11 & 3.73 & 1.10 \\
\hline
\end{tabular}

Source: Field data (2012).

Table 3 shows the results regarding the implications of HR outsourcing for HR Practitioners' job satisfaction. As can be seen in Table 3, there is a significant difference between the mean scores and the standard deviations for almost all the items for job satisfaction. The results revealed that there is a significant difference between the mean score and standard deviation for employees being satisfied with their jobs $(\mathrm{M}=3.58, \mathrm{SD}=1.24)$. There is also a significance difference between the mean score and standard deviation for employees who feel their jobs use their skills and knowledge $(\mathrm{M}=3.92, \mathrm{SD}=0.90)$. This means that Human Resource outsourcing does not have significant impact on Human Resource Practitioners' job satisfaction.

Table 4. Mean and standard deviation regarding turnover intentions

\begin{tabular}{llll}
\hline Responses & N & Mean & SD \\
\hline Want to quit my current job & 12 & 3.17 & 1.34 \\
My job is not secure & 12 & 3.00 & 1.21 \\
Happy about the nature of my work & 12 & 3.00 & 1.21 \\
Happy about my salary & 12 & 3.00 & 1.28 \\
Stressed with my work & 11 & 3.09 & 1.14 \\
Working hours unsatisfactory & 12 & 3.00 & 1.35 \\
Working environment is unsatisfactory & 12 & 3.17 & 1.27 \\
Internal pressures are causing me to leave & 12 & 2.83 & 1.27 \\
I Feel redundant in my Department & 12 & 2.17 & 1.11 \\
I cannot meet my expectations & 12 & 2.33 & 1.44 \\
\hline
\end{tabular}

Source: Field data (2012).

Table 4 shows the results regarding the implications of Human Resource outsourcing for Human Resource Practitioners' turnover intentions. As can be seen in Table 4, there is a significant difference between the mean 
scores and the standard deviations for almost all the items for turnover intentions. The results indicated that there is a significant difference between the mean score and standard deviation for employees who want to quit their jobs $(\mathrm{M}=3.17, \mathrm{SD}=1.34)$. A significance difference also exist between the mean score and standard deviation for employees who also feel redundant in their departments as a result of HR outsourcing activities $(\mathrm{M}=2.17$, $\mathrm{SD}=1.12$ ). This suggests that Human Resource outsourcing does not have significant impact on Human Resource Practitioners' turnover intentions.

\section{Discussion}

This study investigated the implications of Human Resource outsourcing for Human Resource Practitioners work behaviors in the mobile telecommunication industry in Ghana. The study also tried to identify the Human Resource Management functions that are more likely to be outsourced and the implications of Human Resource outsourcing for Human Resource Practitioners' work behaviors such as organisational commitment, job satisfaction and turnover intentions. According to the findings, firms in the mobile telecommunication industry are more likely to outsource their recruitment activities as well as employee training, employee health and safety management and human resource information system activities. This finding is consistent with the findings from previous studies like Armstrong (2003), Datar (2003), Maidment (2003), Vernon et al. (2000), and Hall and Torrington (1998) who had similar findings to suggest that recruitment activities, employee training, employee health and safety and human resource information system activities (such as payroll administration and social security) are more likely to be outsourced. This finding is likely to suggest that many mobile telecommunication companies consider these Human Resource Management activities as time consuming and expensive to provide internally. Possible explanation may also be that these companies may want to outsource these Human Resource Management functions in order to concentrate on core businesses and thus depend on external expertise for these services (Cooke et al., 2005).

Although unpredictable, the findings also suggested that Human Resource outsourcing activities do not have significant impact on Human Resource Practitioners' organisational commitment. This finding is quiet surprising and inconsistent with previous findings from (De-Corte \& Lieven, 2008; Lepak \& Snell, 1999; Bigley \& Pearce, 1998) who highlighted lower levels of organisational commitment among employees as a result of Human Resource outsourcing. The findings suggested that Human Resource Practitioners are still committed to their current employers even though some of their core jobs are being outsourced. However, it is possible that Human Resource Practitioners exhibit partial and inconsistent commitment to their employer organisations in order to keep their jobs (Tsui, Pearce, Porter \& Tripoli, 1997). Outsourcing alone may not constitute the ground for lower levels of organisational commitment among employees. Probably, the increasing unemployment situation among graduates may explain why employees are still committed to their employers despite the perceived implications of Human Resource outsourcing.

Contrary to the expectations, this study found that outsourcing Human Resource Management activities does not lead to job dissatisfaction among HR practitioners. The present finding suggests that Human Resource outsourcing does not have significant impact on Human Resource Practitioners' job satisfaction as many employees are still happy about their working conditions and consequently satisfied with their jobs. However, this finding is inconsistent with the previous findings that low levels of job satisfaction exist among employees as a result of Human Resource outsourcing activities (Kabst \& Giardini, 2008; Dessler, 2008; Ivancevich, 2007; Reilly \& Williams, 2006). This finding provides insight into thinking that perhaps these mobile telecommunication companies rely heavily on extrinsic motivational strategies than intrinsic motivation to make employees satisfied. Since unemployment is increasingly exponentially in many economies, it is possible also that employees' would want to keep their jobs by exhibiting positive feelings toward their employers and jobs.

The study further found that Human Resource outsourcing activities do not have significant impact on Human Resource Practitioners' turnover intentions. This finding demonstrates that outsourcing Human Resource Management activities does not lead to employees' quitting their jobs.

According to this finding, many Human Resource Practitioners' are still interested in working with their current employers despite the increasing rate of Human Resource outsourcing in their firms. This finding is also inconsistent with the findings from the previous studies that high levels of turnover intentions are associated with Human Resource outsourcing (Beechler \& Woodward, 2009; Tarique \& Schuler, 2010; Charara, 2004; Dobbs, 2004; Deery \& Kinnie, 2004; Kiplinger, 2009; Kennedy et al., 2002; Nelson et al., 1995). However, due to the increasing global unemployment, graduates are not willing to lose their jobs just because some of their roles are outsourced. More importantly, it is imperative to note however that these findings are not context-free. The findings from this study need to be considered in the Ghanaian context. It is believed that national context with 
its cultural values and beliefs may moderate the effect of Human Resource outsourcing activities on employees' attitudinal and behavioral outcomes (Beauregard \& Henry, 2009).

Particularly, Spector et al. (2007) argued that national cultures can affect the intensity of the relationships between organisational practices and their effects on job satisfaction, organisational commitment and turnover intentions. As a collectivist culture, Ghanaians are more inclined toward building a sense of belonging which may not permit unnecessary intentions to quit among employees. These cultural values and beliefs together with graduates' unemployment may reinforce some level of organisational citizenship behaviors. Therefore, these findings must be considered in the context of the current global economic crisis. Further, the unemployment among graduates makes employees willing to accept any employment conditions established by employers. In addition, it is observed that high unemployment rates may discourage bad organisational citizenship behaviors such as high levels of turnover intentions, low levels of organisational commitment and job satisfaction among employees. Consequently, the exponential growth of Human Resource outsourcing may not necessarily lead to negative organisational citizenship behaviors among Human Resource Practitioners.

\section{Conclusion}

This study has made several contributions to the current literature about the resource-based theory (RBT) of the firm as well as the Human Resource outsourcing. The resource-based theory provided a theoretical lens for examining the implications of Human Resource outsourcing for Human Resource Practitioners work behaviors. This was vital if a better understanding was to be developed about the implications of Human Resource outsourcing for Human Resource Practitioners. This study has contributed to closing the literature gap in Human Resource outsourcing in Ghana. The study has provided enough evidence that recruitment, employee training, employee health and safety management and human resource information system activities are more likely to be outsourced by mobile telecommunication firms. It was also evident that Human Resource Practitioners job satisfaction, organisational commitment and turnover intentions are not greatly influenced by Human Resource outsourcing activities alone. The study explains that the global economic crisis with its increasing unemployment and financial crises as well as the differences in national cultures can moderate the impact of Human Resource outsourcing activities for Human Resource Practitioners work behaviors.

At the practical level, this study has several managerial implications since the findings provide understanding for those management decisions required to support and facilitate positive organisational behaviors. First, although Human Resource outsourcing activities did not have any significant impact on Human Resource Practitioners work behaviors, management teams must commit to reinforce positive employee work behaviors through both intrinsic and extrinsic motivational factors. Second, firms in the mobile telecommunication industry must focus on internal investment on their Human Resources. This is because commitment to invest in strategic training and development build sufficient internal strengths for distinctive and sustained competitive advantage. This is because internal skills, knowledge, abilities and capabilities when built can create value which underpins the assumptions of resource-based theory.

Like every research, this study has its own limitations. One obvious limitation of a descriptive survey methodology is that the results are based on self-reports which may bias the findings. Qualitative research methodologies could have provided a better understanding of the results since quantitative data alone may provide limited understanding of employee work behaviors. Finally, the sample size was small and moreover this research is industry-specific and country-specific which limit the generalisation of the results to other industries and countries. These limitations can be addressed in future studies. It would be interesting for future research to use qualitative research methodologies to provide better understanding of Human Resource outsourcing and employee work behaviors. This would help elicit in-depth information about Human Resource outsourcing and Human Resource Practitioners work behaviors from the target population. Future line of research could also conduct a longitudinal study that examines the changes in employee commitment, job satisfaction and intention to quit as a result of Human Resource outsourcing over a period of time. Finally, future researchers might investigate how national cultures and national economic situations mediate the impact of Human Resource outsourcing on Human Resource Practitioners' work behaviors.

\section{References}

American Management Association. (1997). Outsourcing: The AMA survey. AMA Research Report. New York: AMA.

Angle, H. L., \& Perry, J. L. (1981). An empirical assessment of organizational commitment and organizational effectiveness. Administrative Science Quarterly, 26(1), 1-14. http://dx.doi.org/10.2307/2392596 
Armstrong, J. S. (2001). Principles of forecasting: A handbook for researchers and practitioners. United States of America: Kluwer Academic Publishers. http://dx.doi.org/10.1007/978-0-306-47630-3

Armstrong, M. (2003). A handbook of human resource management practices (9th ed.). London: Kogan Page.

Armstrong, M. (2006). A hand book of human resource management practices (10th ed.). London: Kogan Page.

Kearney, A. T. (2009). The shifting geography of offshoring. Chicago, IL: AT Kearney Inc.

Babou, C. A. (2010). Decolonization or national liberation: Debating the end of British colonial rule in Africa. The ANNALS of the American Academy of Political and Social Science, 632(1), 41-54. http://dx.doi.org/10.1177/0002716210378647

Barak, M. E., Levin, A., Nissly, J. A., \& Lane, C. J. (2006). Why do they leave? Modeling child welfare workers turnover intentions. Children and Youth Services Review, 28, 548-577. http://dx.doi.org/10.1016/j.childyouth.2005.06.003

Barney, J. B. (1991b). The resource-based view of a strategy: Origins, implications and prospects. Journal of Management, 17, 197-211. http://dx.doi.org/10.1177/014920639101700107

Barnum, S. N. (2001). Network security-guarding against the digital age bad guys. ABN Ambro Investment Analysis Report.

Bartlett, B. (2004). How outsourcing creates jobs for American. National Center for Policy Analysis.

Baruch, Y., \& Hind, R. (1999). Perpetual motion in organizations: Effective management and the impact of the new psychological contracts on survivor syndrome. European Journal of Work and Organizational Psychology, 8(2), 295-306. http://dx.doi.org/10.1080/135943299398375

Beauregard, T. A., \& Henry, L. C. (2009). Making the link between work-life balance practices and organizational performance. Human Resource Management Review, 19, 9-22. http://dx.doi.org/10.1016/j.hrmr.2008.09.001

Beechler, S., \& Woodward, I. C. (2009). The global war for talent. Journal of International Management, 15 , 273-285. http://dx.doi.org/10.1016/j.intman.2009.01.002

Benson, J., \& Littler, C. (2002). Outsourcing and workforce reductions: an empirical study of Australian organizations. Asia Pacific Business Review, 8(3), 16-30. http://dx.doi.org/10.1080/713999154

Brown, D., \& Wilson, S. (2005). The black book of outsourcing: How to manage the changes, challenges and opportunities. New York: John Wiley \& Sons, Inc.

Chaffey, D. (2003). E-business and e-commerce management: strategy, implementation and practice. Harlow: Financial Times Prentice Hall.

Charara, J. (2004). Impact of outsourcing lasts years. People Management, 2(4), 15-18.

Cheng, G. H. L., \& Chan, D. K. S. (2008). Who suffers more from job insecurity? A Meta-Analytic review. Applied Psychology: An International Review, 57(2), 272-303. http://dx.doi.org/10.1111/j.1464-0597.2007.00312.x

Cook, J., \& Wall, T. (1980). New work attitude measures of trust, organizational commitment and personal need non-fulfillment. Journal of Occupational Psychology, 53, 39-52. http://dx.doi.org/10.1111/j.2044-8325.1980.tb00005.x

Cook, M. F. (1999). Outsourcing human resource function: Strategies for providing enhanced HR services at lower cost. New York: AMACOM.

Cooke, F. L., Shen, J., \& Mcbride, A. (2005). Outsourcing human resources as a competitive strategy? A literature review and an assessment of implications. Human Resource Management, 44(4), 413-432. http://dx.doi.org/10.1002/hrm.20082

Cooper-Harkim, A., \& Viswesvaran, C. (2005). The construct of work commitment: Testing an integrative framework. Psychological Bulletin, 131(2), 241-259. http://dx.doi.org/10.1037/0033-2909.131.2.241

Crane, D. (1999). Renewed focus on financial performance. Outsourcing Journal. Retrieved from http://www.Outsourcing-Journal.com/issues/

Crolius, R. W. (2006). America's workforce crisis. American Ceramic Society, $2,8$.

Datar, R. (2003). BPO adoption in Asia Pacific: A demand-side perspective. Gartner Research. 
Deery, S., \& Kinnie, N. (2004). Introduction: The nature and management of call centre work. In Deery, S., \& Kinnie, N. (Eds.), Call centres and human resource management: A Cross National Perspective (pp. 1-22). Basingstoke: Palgrave Macmillan.

Dell, D. (2004). HR outsourcing: Benefits, challenges and trends. New York: The Conference Board.

Dessler, G. (2008). Human resource management (25th ed.). Singapore: Pearson Prentice Hall.

Dobbs, L., \& Wadhwani, S. (2004). Is outsourcing killing jobs? Optimize, 19-21.

Drucker, P. F. (2002). Managing in the next society. New York: St. Martin's Press.

Duening, T. N., \& Click, R. L. (2005). Essentials of business process outsourcing. Retrieved May 13, 2011, from http://www.wiley.com/WileyCDA/WileyTitle/productCd-0471655775.html http://dx.doi.org/10.1002/9781118386279

Dillon, R. W., Madden, J. T., \& Firtle, H. N. (1993). Essentials of Marketing Research. Irwin Homewood, Boston.

Eleanna, G., \& Papalexandris, N. (2005). Outsourcing of human resource management service in Greece. International Journal of Manpower, 26(94), 382-396.

Engardio, P. (2006). The future of outsourcing: How it's transforming whole industries and changing the way we work. Business Week, 39(69), 50-58.

Farrell, D. (2004). A richer future for India. The MeKinsey Quarterly. Retrieved from $\mathrm{http}: / / \mathrm{www} . \mathrm{mckinseyquarterly.com/article \_ page.aspx}$ ?ar=1440\&L2+7\&L 3=10\&srid=6\&g

Finn, W. (1999). The ins and outs of human resources. Director, 53, 66-67.

Forbes Magazine. (2011). The world's friendliest countries. Retrieved July 10, 2011, from http://blogs.forbes.com/bethgreenfield/2011/04/08/the-worlds-friendliest-countries/

Freeman, S. J., \& Cameron, K. S. (1993). Organizational downsizing: A convergence and reorientation framework. Organization Science, 4, 10-29. http://dx.doi.org/10.1287/orsc.4.1.10

Gainey, T. W. (2003). The outsourcing of training and development: Factors impacting client satisfaction. Journal of Management, 29(2), 207-229. http://dx.doi.org/10.1177/014920630302900205

Ghana Energy Commission. (2005). Strategic national energy plan (2005-2025). Retrieved June 26, 2010, from http://www.energycom.gov.gh

Ghana Statistical Service. (2010). Ghana's economic performance (2009) in figure. Government Report: Accra: Ghana Statistical Service.

Ghana Telecommunications $\quad$ Report. (2012). Retrieved from http://www.marketresearch.com/Business-Monitor-International-v304/Ghana-Telecommunications-Q4-657 $4272 /$

Greer, C., \& Youngblood, S. A. (1999). Human resource management outsourcing: make or buy decision. Department of Management, College of Business Administration, University of Texas at Arlington.

Haines, R. (2009). Organizational outsourcing and the implications for human resource management. In Collings, D. G., \& Wood, G. (Eds.), Human resource management: A critical approach. Oxon: Routledge.

Hall, L., \& Torrington, D. (1998). The human resource function: The dynamics of change and development.

Hallard, K. (2011). The advent of nearsourcing. Retrieved July 11, 2011, from $\mathrm{http}: / /$ www.outsourcingyearbook.com/wpcontent/uploads/./oy2011_04_13.pdf

Hewitt Associates. (2007). LLC SWOT Analysis. 1-8.

Hirshman, B., Cords, R., \& Hunter, B. (2005). Strategic direction. Airline Business, 21(10), 59. Retrieved July 11, 2011, from http://www.bpovoice.com/profiles/blogs/is-ghana-the-next-bpo-hotspot

Human Resource Outsourcing Survey Report. (2004, July). 12-34.

Ivancevich, J. M. (2007). Human resource management (2nd ed.). New York: McGraw-Hill.

Jasper, W. (2003). Your job may be next. The New American, 19(5), 28-29.

Kabst, R., \& Giardini, A. (2008). Recruitment process outsourcing (translated title): Eine Szenariostudie zur Akzeptanz von Outsourcing-Maßnahmen in Der Personalauswahl [Electronic Version]. Zeitschrift für Personal for schung, 22(4), 370-388. 
Kakabadse, N., \& Kakabadse, A. (2002). Trends in outsourcing: Contrasting USA and Europe. European Management Journal, 20(2), 189-198. http://dx.doi.org/10.1016/S0263-2373 (02)00029-4

Karen, B., \& Gregory, G. (2004). Sourcing strategies for the transnational organization. Journal of International Human Resource Management, 8(4).

Kaufmann, D., Kraay, A., \& Mastruzz, M. (2008). Governance matters VI: Aggregate and individual governance indicators: 1996-2006. Retrieved July 10, 2011, from http://info.worldbank.org/governance/wgi/pdf/govmatters6.pdf http://dx.doi.org/10.1596/1813-9450-4654

Kennedy, J. F., Holt, D. T., Ward, A. W., \& Rehg, M. T. (2002). The Influence of outsourcing on job satisfaction and turnover intentions of technical managers. Human Resource Planning, 25(1), 23-31

Kiplinger's Personal Finance. (2009). On the job and feeling guilty, September, 5-8.

Klaas, B. S., McClendon, J. A., \& Gainey, T. W. (2001). HR outsourcing and its impact: The role of transaction costs. Personnel Psychology, 52, 113-136. http://dx.doi.org/10.1111/j.1744-6570.1999.tb01816.x

KPMG International. (2006). Asian outsourcing: The next wave. Australia: The Economist Intelligence Unit Ltd.

Lepak, D. P., \& Snell, S. A. (1999). Virtual HR: Strategic human resources in the 21 century. Human Resource Management Review, 24, 31-48.

Leverett, H. M., Megley, J. E., \& Kamery, R. H. (2004). Outsourcing evolution and effect on the U.S. economy. Proceeding of the Academy of Legal, Ethical and Regulatory Issues, 8(2), 175-180.

Lievens, F., \& De Corte, W. (2008). Development and test of a model of external organizational commitment in human resources outsourcing. Human Resource Management, 47(3), 559-579. http://dx.doi.org/10.1002/hrm.20232

Linder, J. C. (2004). Transformational outsourcing. Sloan Management Review, 45(2), 52-58.

Lyons, T. F. (1981). Propensity to leave scale of 1971. In Cook, J. D., Hepworth, S. J., Wall, T. D., \& Warr, P. B. (Eds), Experience of work: Acompendium and review of 249 measures and their use. New York: Academic Press.

Macdonald, S., \& Macintyre, P. (1997). The generic job satisfaction scale: Scale development and its correlates. Employee Assistance Quarterly, 13(2). http://dx.doi.org/10.1300/J022v13n02_01

Mahoney, C., \& Brewster, C. (2002). Outsourcing the human resource function in Europe. Journal of Professional Human Resource Management, 27, 23-28.

Maidment, F. H. (2003). Human resources (13th ed.). The United States of America: McGraw Hill/Dushkin.

Malcolm, M. (2005). Telstra dives as \$10bn plans unveiled. The Age, Retrieved 30 April 2011.

Marquez, J. (2007b). Not in for outsourcing. Workforce Management, 86(3), 1-5.

McCormick, T. (2011). Outsourcing onshore or offshore? Accountancy Ireland, 43(2), 74-82.

National Communication Authority. (2012). Communications infrastructure (communication tower) Licence. Retrieved from http://www.nca.org.gh/downloads/TOWER_LICENCE.pdf

Nelson, D. L., Quick, J. C., Hitt, M. A., \& Mosel, D. (1990). Politics, lack of career progress and work-home conflict: Stress and strain for working women. Sex roles, 23(3/4), 169-185. http://dx.doi.org/10.1007/BF00289864

O'Reilly, C., \& Chatman, J. (1986). Organizational commitment and psychological attachment: The effects of compliance, identification and internalization on prosocial behavior. Journal of Applied Psychology, 34, 487-516.

Obour, S. K. (2010). Ghana's electricity palaver. Retrieved June 26, 2011, from http://www.ghanaweb.com/GhanaHomePage/NewsArchive/artikel.php?ID=181-688

Osiakwan, E., \& Foster, W. (2004). Negotiating the Net: the Case of Ghana. Retrieved June 27, 2011, from http://www.cidcm.umd.edu/ntn/

Parveez, N. (2009). Is Ghana the next BPO hotspot? Retrieved July 11, 2011, from http://www.bpovoice.com/profiles/blogs/is-ghana-the-next-bpo-hotspot

Penrose, E. (1959). The theory of the growth of the firm. New York: Wiley. 
Porter, L., Steers, R., Mowday, R. T., \& Boulian, P. V. (1974). Organizational commitment, job satisfaction and turnover among psychiatric technicians. Journal of Applied Psychology, 59, 603-609. http://dx.doi.org/10.1037/h0037335

Porter, M. E. (1985). Competitive advantage: Creating and sustaining superior performance. New York: Free Press.

Purcell, J. (1996). Contingent workers and human resource strategy: Rediscovering the core periphery dimension. Journal of Professional Human Resource Management, 16-23.

Reed, A. (2001). Innovation in human resource management: Tooling up for the talent wars. London: CIPD house.

Reilly, P., \& Williams, T. (2006). Strategic HR: Building the capability to deliver. Great Britain: Gower Publishing Limited.

Sethi, M., \& Sethi, D. (2011). Human resource outsourcing: Analysis based on literature review. International Journal of Innovation, Management and Technology, 2(2), 127-135.

Sourcing line. (2011). Global sourcing and outsourcing locations: Ghana. Retrieved July 10, 2011, from http://www.sourcingline.com/outsourcing-location/ghana

Spector et al. (2007). Cross-national differences in relationships of work demands, job satisfaction and turnover intentions with work-family conflict. Personnel Psychology, 60, 805-835. http://dx.doi.org/10.1111/j.1744-6570.2007.00092.x

Tarique, I., \& Schuler, R. S. (2010). Global talent management: Literature review and integrative framework, and suggestions for further research. Journal of World Business, 45(2), 122-133. http://dx.doi.org/10.1016/j.jwb.2009.09.019

Tsui, A. S., Pearce, J. L., Porter, L. W., \& Tripoli, A. M. (1997). Alternative approaches to the employee-organization relationship: Does investment in employees pay off? Academy of Management Journal, 40, 1089-1121. http://dx.doi.org/10.2307/256928

Ulrich, D. (1998). Measuring human resources: An overview of practice and a prescription for results. Human Resource Management, 36, 320. http://dx.doi.org/10.1002/(SICI)1099-050X(199723)36:3<303::AID-HRM3>3.0.CO;2-\#

Ward, S. (2004). Outsourcing research: What is your position? Business Information Review, 21. SAGE Publication.

Wernerfelt, B. (1984). A Resource-based view of the firm. Strategic Management Journal, 5. http://dx.doi.org/10.1002/smj.4250050207

Worall, L., \& Cooper, C. (1997). Quality of working life: 1997 survey of manager's changing experiences. Institute of Management, London.

Wright, C. (2008). Reinventing human resource management: Business partners, internal consultants and the limits to professionalization. Human Relations, 61(8), 1063-1086. http://dx.doi.org/10.1177/0018726708094860

\section{Copyrights}

Copyright for this article is retained by the author(s), with first publication rights granted to the journal.

This is an open-access article distributed under the terms and conditions of the Creative Commons Attribution license (http://creativecommons.org/licenses/by/3.0/). 